\title{
Caracterizaciòn morfológica y molecular de lulo (Solanum quitoense Lam) en Pachavita-Boyaca
}

\section{Morphological and molecular characterization of lulo (Solanum quitoense Lam.) in Pachavita-Boyaca}

\section{Ana Cruz Morillo Coronado ${ }^{1}$,Andrea del Pilar Rodríguez Fagua ${ }^{2}$,Yacenia Morillo Coronado ${ }^{3}$}

${ }^{1}$ Docente asociado Universidad Pedagógica y Tecnológica de Colombia (UPTC)

${ }^{2}$ Investigador grupo Competitividad, Innovación y Desarrollo Empresarial (CIDE), UPTC.

${ }^{3}$ Docente Ocasional Universidad de los Llanos

\section{Resumen}

El lulo (Solanum quitoense Lam.) es un frutal exótico, originario de la región Andina, considerado promisorio por sus propiedades organolépticas, nutricionales, medicinales y agroindustriales. Sin embargo su potencial genético en el país, es aún subutilizado y por lo tanto el objetivo de esta investigación fue caracterizar la diversidad genética de 21 materiales de lulo usando descriptores morfológicos y marcadores microsatélites RAMs. La caracterización morfológica permitió determinar que los caracteres más discriminantes son el eje ecuatorial del fruto (EJE), peso del fruto (PF), volumen de jugo (VJF), eje polar del fruto (EJP) y longitud del tallo (LT), color de la pulpa (FcMeso) y grosor de la cáscara (DEPI) y longitud de espinas en el tallo (TET). El análisis mediante el coeficiente de Nei-Li permitió la conformación de tres grupos los cuales no muestran una asociación directa con la zona geográfica, o la presencia o ausencia de espinas. Los parámetros de diversidad genética muestran la existencia de variabilidad genética superior a lo reportado en otros estudios de diversidad genética en lulo y especies relacionadas en el país. En general los marcadores morfológicos y moleculares determinaron que en Pachavita, existe variabilidad que puede ser utilizada en programas de mejoramiento genético de la especie.

Palabras clave: Frutal andino, Diversidad, Microsatélites RAMs. 
68

\section{Abstract}

Lulo (Solanum quitoense Lam.) is an exotic fruit, native to the Andean region that is considered promising because of its organoleptic, nutritional, medicinal and agroindustrial properties. However, the genetic potential in this country is still underutilized and, therefore, the objective of this research was to characterize the genetic diversity of 21 lulo materials using morphological descriptors and microsatellite markers (RAM). The morphological characterization showed that the more differentiating characteristics included the equatorial axis of the fruit (EJE), fruit weight (PF), juice volume (VJF), polar axis of the fruit (EJP), stem length (LT), pulp color (FcMeso), peel thickness (DEPI) and length of thorns on the stem (TET). The analysis with the Nei-Li coefficient resulted in three groups that did not have a direct association with the geographical area or with the presence or absence of thorns. The parameters of genetic diversity showed the existence of higher genetic diversity than that reported in other studies on lulo and related species in this country. In general, the morphological and molecular markers demonstrated that, in Pachavita, there is variability that can be used in breeding programs for this species.

Keywords: Andean fruits, diversity, Microsatellite RAM.\}

\section{Introduction}

Lulo (Solanum quitoense Lam.) is a species of the Solanaceae family, native to the Andes, whose primary center of diversity is located in Colombia and Ecuador, which are the main producing countries. It is considered a promising fruit because of characteristics such as its bittersweet flavor, aroma, flesh color, nutritional content, antioxidant, medicinal and agroindustrial properties that make it attractive both in the domestic and international markets (Ajoy \& Sailendra, 2015; Cárdenas, 2009) .

In Colombia, lulo is grown at different altitudes; it grows spontaneously in the understory, mostly intercropped with coffee (Coffea arabica L.), with two ecotypes: Solanum quitoense var. septentrionale (with thorns, adapted to understory) and Solanum quitoense var. quitoense (thornless material adapted to greater sun exposure), while there is only one bred var. (La Selva cultivar) (Colombia, 2014; D. 
Mejía, Gaviria, Duque, Rengifo, \& Aguilar, 2012; Dashchi, B. Abdollahi, \& Bernousi, 2012)(Chaparro et al., 2015). Lulo production in Colombia has increased $5.6 \%$ in the last ten years, indicating the economic importance of this fruit in this country. However, this increase was due to the cultivated area and not to income as such, so research aimed at implementing production technologies to improve profitability is necessary (E. Zietkiewicz \& Rafalfki, 1994)(Stabilization et al., 2015). This country has optimum environmental conditions for crop development, but there have been few studies on the collection, characterization and establishment of genebanks, which are necessary for obtaining new plant materials. In fact, most of the Colombian production (over $74 \%$ ) comes from smallholders, lacking advanced technology. Also, this species is still in the species domestication process with the following characteristics: allogamy, narrow ecological adaptation, presence of thorns, latency, and lots of seeds, among others. Therefore, it is necessary to characterize and evaluate the genetics, which would lead to understanding the dynamics to which these materials are subjected in the environment and by farmers, which influences the processes of genetic variability in this species (Colombia, 2014)(Enciso, Martínez, Lobo, \& Barrero, 2010)(Cortés Díaz, Prieto Suárez, \& Rozo Nuñez, 2015).

The potential use of plant genetic resources depends on the existing knowledge; as such, in Colombia, collections of lulo and related taxa have been carried out in the main producing regions; some of this material is kept in the System Germplasm Bank Of Colombian Nation For Food and Agriculture, by Corpoica, which has 77 accessions of S. quitoense, 8 for $S$. hirtum, 17 for $S$. pseudolulo, 5 for $S$. vestissimum, 2 for $S$. pectinatum, 2 for $S$. sessiliflorum, 1 for $S$. stramonifolium and 2 for $S$. ferox, all in the Lasiocarpa section (Colombia, 2014). To estimate the genetic diversity of plants, different methods can be used, including morphological, biochemical and molecular markers. Morphological characterization studies have been conducted as a first approximation of the knowledge of the genetic diversity of the Colombian Lulo, and related species, resulting in the existence of polymorphism in both qualitative and quantitative characteristics (Enciso et al., 2010; Fory et al., 2011; Lobo, Medina, Delgado, \& Bermeo, 2007). Since morphological characteristics are influenced by the environment and the development stage of the plant, DNA markers have been developed, which have become an important tool for crop improvement, especially in genetic diversity studies (M. Abdul \& Singh, 2015). Different systems have used markers to determine genetic variation in Colombian Lulo germplasms, including interspecific hybrids of $S$. hirtum $\times S$. quitoense, demonstrating once again the genetic 
potential that can be used in obtaining new planting materials(Enciso et al., 2010; Fory et al., 2011)(M. Henareh, Dursun, Mandoulakani, \& Haliloğlu, 2016).

Among the markers based on PCR (Polymerase Chain Reaction), microsatellites or SSR (Simple Sequence Repeat) are the preferred technique for studies on genetic diversity in plants because of their high polymorphism, abundance and codominant inheritance. Microsatellite markers, RAMs (Random Amplified Microsatellite), also known as ISSR (Inter-Simple Sequence Repeat), are a simple, fast, inexpensive technique that requires no prior knowledge of the genome sequence or specialized technical support. ISSR analyses involve PCR amplification of adjacent regions between inversely oriented microsatellites, using simple sequence repeat motifs ( $\mathrm{di}_{\text {, tri, tetra or }}$ pentanucleotide); containing two to four arbitrarily end anchored nucleotides, $3^{\prime}$ or 5', often called degenerated nucleotides (M. Riascos, Santacruz, Lagos, \& Checa, 2012). This technique combines the advantages of AFLP (Amplified Fragment Length Polymorphism) microsatellites, or SSR, with the universality of RAPD (Random Amplified Polymorphic DNA). They have been successfully used in different species of the Solanum genus in studies on conservation, phylogeny, genetic diversity, varietal identification and genes and in predicting favorable heterotic combinations (Medina, Lobo, \& Martínez, 2009; Miller \& Diggle, 2003; Muñoz, Rodríguez, \& Bermúdez, 2013). The development of more than one marker system along with genotyping seems to be the most accurate and reliable way to determine genetic diversity and structures in natural populations because they allow for better coverage of genomic regions, thus minimizing experiment error. In this context, the objective of this research was to use a combination of morphological and molecular markers (RAMs) to make a more detailed analysis of the genetic diversity of lulo (Solanum quitoense Lam.) in the department of Boyacá, especially in the province of Neira, with the view of establishing strategies for the collection, conservation and efficient management of phytogenetic resources.

\section{Methodology}

\section{Field Collection and establishment}

Twenty-one lulo materials were collected, both cultivated and wild, in the department of Boyacá, Neira Province, specifically in the municipality of Pachavita, Soaquira district, at an altitude of $1,985 \mathrm{msnm}$ with an average temperature of $16^{\circ} \mathrm{C}$, and 
Sacaneca district, at an altitude of $2,148 \mathrm{msnm}$ with an average temperature of $17^{\circ} \mathrm{C}$ (Table 1).

\section{Morphological Characterization}

Four plants from the collected lulo materials were used for the characterization, which were evaluated with the descriptors developed by Wolf et al. (2007) (Colombia, 2014). A digital colorimeter, Minolta, was used with the CIELab parameters " $L$ ", " $a$ " and " $b$ " for the evaluation of the qualitative variables, such as the color of the seed coat (FcEpi), flesh color (FCMeso) and seed color (CSEM); for each fruit, three readings were taken at the equatorial diameter, where $L$ indicated lightness, where values of 0 are black and 100 are white, values of "a" less than 0 are green and greater than 0 are red, and "b" values less than 0 indicate blue and greater than 0 are yellow.

The quantitative variables, such as the length of the stem (LT), which was taken from the base to the first true branch; length of stem thorns (TET), leaf length (LH), length of petiole (LP) and leaf width (AH), were taken in the field with a tape measure. Similarly, the number of lobes of the leaves (NLH), the total number of lobes per leaf and number of flowers per plant (NFINF) of each material were measured. For the analyzes of the fruits, four samples for each material were taken in the same developmental stage and brought to the Laboratory of Plant Physiology of the Pedagogical and Technological University of Colombia in Tunja to determine the polar axis (EJE-vertical) and equatorial axis (EJE-horizontal), which were recorded with a caliper as was the thickness of the peel (DEPI). The length of the fruit peduncle (LPF) was also measured. A precision scale, to the nearest $0,001 \mathrm{~g}$, was used to weigh the fruits (PF) and seeds (PCS), calculating the weight of seeds per fruit (PSF). The pH was measured with a potentiometer precalibrated with buffer solutions of $\mathrm{pH} \mathrm{7,0}$ and 4,0; the Brix (Brix) degrees were determined with a digital refractometer, Hanna, with a range 0 to $85 \%$ and an accuracy of $0.1^{\circ}$ Brix, along with the juice volume of five fruits (VJF) and the titratable acidity (ATT), which were used in the following equation.

$$
\% \text { Acidity }=((A \times B \times C)) / D \times 100
$$

Where,

$A=$ Volume of spent $\mathrm{NaOH}$

$B=$ Normality of $\mathrm{NaOH}(0.097)$ 
$\mathrm{C}=$ equivalent weight expressed in $\mathrm{g}$ of predominant acid in the fruit (citric acid, $0,064 \mathrm{~g}$ meq-1)

$\mathrm{D}=$ weight in grams of the sample $(5 \mathrm{~g})$

\section{Molecular characterization}

The molecular characterization was carried out in research laboratories of the Molecular Biology of the Pedagogical and Technological University of Colombia located in Tunja at an altitude of $2,820 \mathrm{~m}$ with an average temperature of $13^{\circ} \mathrm{C}$. The DNA was extracted with the Dellaporta protocol (1983)(Nei \& Li, 1979) and visualized in $0.8 \%$ agarose gels stained with Z-Vision in a MaxiCell Primo EC-340 Gel Electrophoresis System. A Hoefer Dyna Quant 200 fluorometer was used to determine the concentration of each genotype. Seven primers, synthesized by Technologies Inc. (Table 2), were used for the RAM analysis. For the RAM amplification, a reaction cocktail was prepared in a sterile microcentrifuge tube $(1.5 \mathrm{ml})$ to a final volume of 25 $\mu \mathrm{l}$. The reaction mixture was prepared with a $1 \mathrm{X}$ buffer, $1,5 \mathrm{mM} \mathrm{MgCl} 2,0,2 \mathrm{mM}$ dNTPs, $1 \mathrm{U}$ Taq Polymerase, 2 uM primer and $10 \mathrm{ng}$ genomic DNA.

The amplification was carried out in a PTC 100 Programmable Thermal Controller thermocycler (MJ. Research, Inc.). The initial denaturation was at $95^{\circ} \mathrm{C}$ for $5 \mathrm{~min}$; with denaturation at $95^{\circ} \mathrm{C}$ for $30 \mathrm{~s}$, annealing at a temperature of $50^{\circ} \mathrm{C}$ (primer AG $\mathrm{CA}$ ), $55^{\circ} \mathrm{C}$ (primer CCA-TG-CT) and $58^{\circ} \mathrm{C}$ (primer CGA) for $45 \mathrm{~s}$, final extension $72^{\circ}$ $\mathrm{C}$ for $2 \mathrm{~min}, 37$ cycles from denaturation to extension, and finally an extension at $72^{\circ}$ $\mathrm{C}$ for $7 \mathrm{~min}$. The products were separated by electrophoresis in high-resolution $1.2 \%$ agarose gel at 90 volts for 3 hours, visualized with an ultraviolet light trans illuminator. The descriptive statistics were determined with the data obtained from the morphological characterization and a multivariate analysis using InfoStat (Statistical Analysis System View 2015). The principal component analysis was done using the correlation matrix between the characteristics. The main components were plotted on a two dimensional plane to group the characterized accessions.

For the molecular analysis, the genetic similarity was calculated with the similarity coefficient of Nei and Li (1979) (Onamu, Legaria, Rodríguez, Sahagún, \& Pérez, 2016). The genetic diversity parameters were estimated using the TFPGA (Tools For Population Genetic Analyses, version 1.3, 1997) statistical package. The f non-biased statistic was determined with a confidence interval of $95 \%$, according to Wright (1978). The analysis of the Molecular Variance (AMOVA) was done with GenAlEx 6.41. 
73

The morphological and molecular data were used for the cluster analysis with UPGMA and a dendrogram was generated using the statistical package NTSYS (Numerical Taxonomy System for Personal Computer, PC version 2,02).

\section{Results and Discussion}

The principal components analysis demonstrated that the three principal components explained more than $70 \%$ of the observed phenotypic variation. In principal component 1 (PC1), the following variables contributed to the observed variation: the equatorial axis of the fruit (EJE), fruit weight (PF), juice volume (VJF), polar axis of the fruit (EJP) and stem length (LT). For PC2, the variables were: pulp color (FcMeso) and peel thickness (DEPI). Finally, for PC3, it was thorn length on the stem (TET) (Table $3)$.

These characteristics were more discriminating at the time of the morphological evaluation of the lulo genotypes (Solanum quitoense Lam.), as can be seen in the Biplot of principal components 1 and 2, which separated the individuals into four groups according to the characteristics related to each one of the previously mentioned components (Figure 1).

Overall, the greatest variation in the lulo materials collected in the province of Neira was observed in the qualitative and/or quantitative characteristics related to the fruits, followed by the characteristics of the leaves, stems and finally flowers. These results agree with those found by Riascos et al. (2012) (Fory et al., 2011) who morphologically characterized 39 genotypes from the collection of lulo (Solanum quitoense Lam.) at the Universidad de Nariño from the departments of Cauca, Nariño, Valle del Cauca, Risaralda and Antioquia, reporting that the variables related to the fruits, thorns, stems and flowers were the major contributors to the total variation, and that the clusters showed low overlap at the taxon level, which can be attributed to the evolutionary patterns that are different for the two types of attributes, while the quantitative characteristics were affected by the environment and polygenic inheritance, the qualitative ones showed no interaction with the environment, making them highly inheritable (Colombia, 2014).

Among the physicochemical characteristics used for the evaluation of fruit quality, the content of soluble solids (SS), which averaged $13,6^{\circ}$ Brix with $\mathrm{pH}$ values ranging between 2,4 and 3,5 and an overall average of 3,3, indicated that the fruits collected in the province of Neira were mostly bittersweet, which is a desirable characteristic because they have better market acceptance (Lobo et al., 2007). 
Genotypes were seen with desirable values for properties such as stem length, length of petiole, equatorial and polar axis of fruit, $\mathrm{pH},{ }^{\circ}$ Brix, weight of five fruits, weight of 100 seeds, seed weight / fruit, juice volume of five fruits, titratable acidity, orange hue of epicarp and yellow hue of seeds. Higher average values for fruit characteristics are favorable for marketing, and one of the major problems in lulo breeding programs in Colombia is the small size and weight of the fruits, so these materials would be a good alternative for selection processes geared towards finding elite materials that will meet market needs (Lobo et al., 2007).

In this study of lulo genetic diversity (Solanum quitoense Lam.) using seven RAM markers, a total of 357 bands were generated with $94,4 \%$ polymorphism. The number of bands per primer ranged from 43 (CT) to 47 (TG), with molecular weights between 300 and $1,000 \mathrm{bp}$ and percentages of polymorphic loci between 88,6 and $100 \%$ for the ACA and CGA primers, respectively (Table 4). The number of bands and the percentage of polymorphic loci were suitable for estimating the genetic parameters in the evaluated lulo materials because they were higher than those reported in other studies of genetic diversity, both nationally and internationally, that used dominant markers in the germplasm of lulo and other species belonging to the Solanum genus (Enciso et al., 2010)(Miller \& Diggle, 2003; Muñoz et al., 2013)(Rodríguez \& Sosa, 2015). The high percentage of polymorphism detected in this study may have been due to the wild state in which some of the evaluated materials were collected, the use of high-resolution electrophoresis systems, and the fact that morphological variation has already been reported (S. Dellaporta \& Wood, 1983).

The TG primer had the greatest contribution to the observed genetic variation with a genetic differentiation value of (Fst) 0,22 , followed by AG (Fst $=0,19)$ and CGA (Fst = $0,17)$, which means that they are useful markers for genetic diversity studies on Solanum. The average estimated heterozygosity values had a range between 0,33 and 0,40 for the TG and CGA primers, respectively. In general, the primers with repeating motifs, TG CGA, CCA, and AG, showed higher levels of polymorphism. Similar results have been reported in other species of the Solanum genus using ISSR markers (Miller \& Diggle, 2003).

The average estimated heterozygosity value for all of the evaluated lulo materials using seven RAM markers was 0,36 higher than that reported by Enciso et al. (2010)(Fory et al., 2011), who evaluated the genetic diversity of the lulo germplasm bank of Corpoica in Colombia, using COS II markers. Henareh et al. (2016) (Miller \& 
Diggle, 2003) evaluated 93 local tomato varieties from the Eastern Anatolia region of Turkey and northeastern Iran using 14 ISSR markers and reported average estimated heterozygosity values of 0,22 , which demonstrated the existence of genetic variability in the province of Neira that can be exploited in the collection, conservation and breeding of this species. However, genetic diversity studies on other species of the Solanum genus using codominant microsatellite markers have shown values of heterozygosity much higher than those found in this study, which demonstrates the potential of these markers in determining the genetic structure and diversity in natural populations(S. Zhang et al., 2014; Vallejo, Montero, Cecile, Bacles, \& Lepais, n.d.). The low variation in the lulo populations in this country has already been reported by Enciso et al. (2010) (Fory et al., 2011) who attributed these results to the high rate of inbreeding within subpopulations, a low gene flow between them, and the fact that lulo, despite being a cross-pollinated species, may also have self-pollination by andromonoecy(Wright, 1978) .

On the other hand, the Fst value for the whole population was $0,14 \pm$ Fst $=0,01$; according to Wright (1978) (Xiao et al., 2013), this suggests that there was an intermediate level of genetic differentiation, which may have been due to the evolutionary processes that are seen in the natural environment and may indicate the existence of a moderate relationship between the geographical location and the genetic group. By contrast, diversity studies on different Solanum species, both nationally and internationally, have shown higher Fst values, thus showing population structure, low uniformity in allele frequencies and high genetic differentiation in the analyzed subpopulations (Fory et al., 2011)(Miller \& Diggle, 2003; Muñoz et al., 2013).

The UPGMA analysis resulted in three groups (I, II, III) at a level of similarity of 0,60 (Figure 1). In group I, there was grouping of native or mixed lulos that are maintained by farmers in the Soaquira District; these materials are characterized by low domestication traits (large seed quantity, abundant pubescence, thorns). In this group, the material had a lower similarity value $(0,25)$ with the rest of the materials; this may have been due to the characteristics of the material and geographical separation because one of the materials was collected at a high altitude (S. Dellaporta \& Wood, 1983).

In group II, there was a laxer distribution of the lulo materials because genotypes from both districts (Soaquira and Sacaneca) were seen, showing that gene flow may exist between these materials, along with the exchange of seeds by farmers in this 
76

area. Here, there were lulo materials that were thornless, thorny, thick and mixed that were characterized by high coefficients of variation in the qualitative and quantitative characteristics, especially those related to the fruits (S. Dellaporta \& Wood, 1983), characteristics that are interesting from the marketing point of view and that will help solve the problem of lack of supply of materials with desirable agronomic and agroindustrial characteristics (Lobo et al., 2007). 


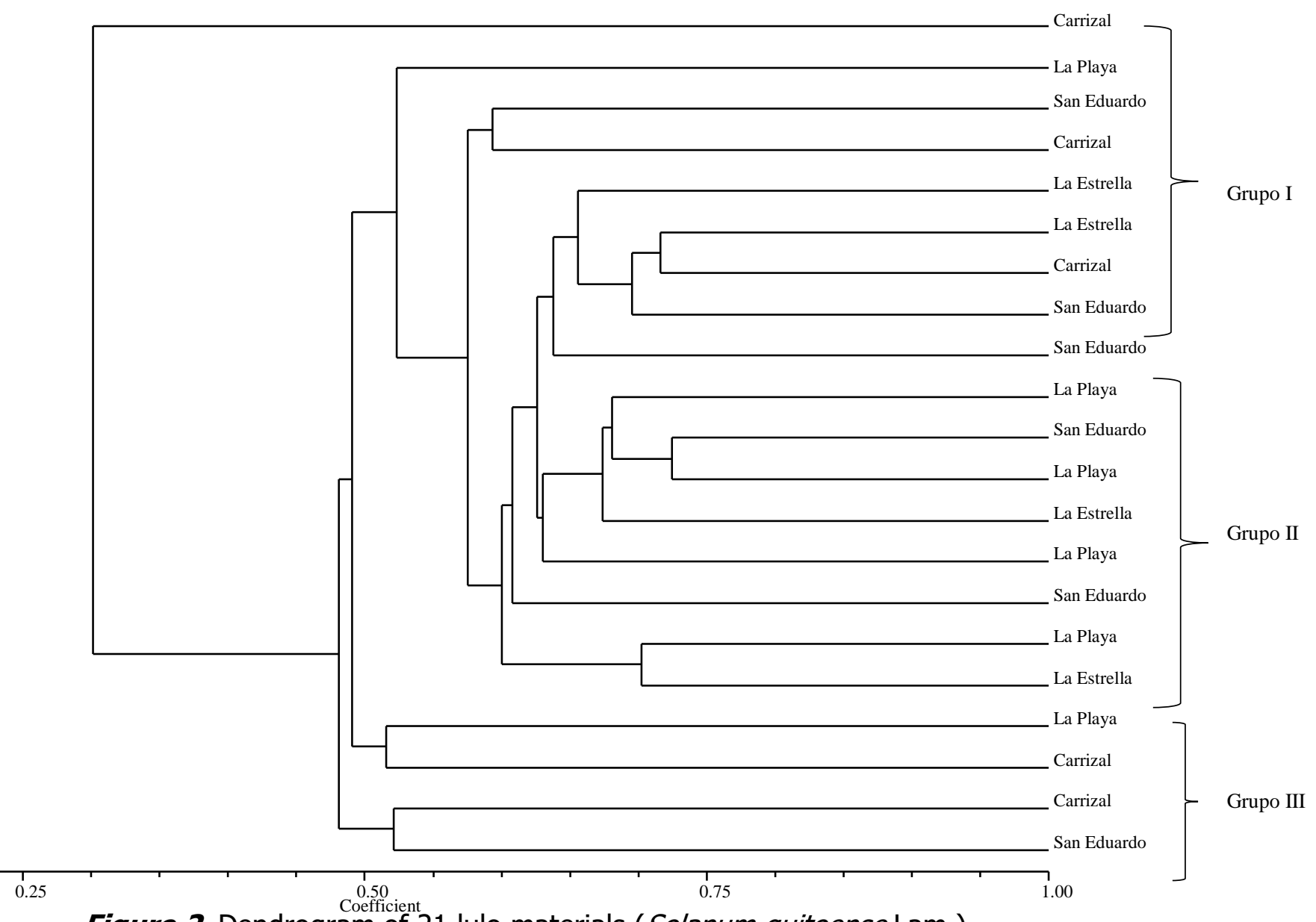

Figure 2. Dendrogram of 21 lulo materials (Solanum quitoense Lam.)

At a similarity level of 0,50 , there was a third group that contained three materials collected from the Carrizal farm with highly variable characteristics; natives that form part of the germplasm have been maintained by this farmer over time, therefore these materials are in the process of domestication. In general, the groupings had a loose distribution of materials with no relationship with the geographical sites; rather, there was gene flow between them. Furthermore, there were no associations related to the presence or absence of thorns as has been reported in other studies on the genetic diversity of lulo (Lobo et al., 2007).A study on the genetic diversity in the Colombian germplasm showed similar results, attributed to the genetic nature of the species, to the processes of evolution of materials in their natural environment and to the type of molecular markers that was used (Enciso et al., 2010; Fory et al., 2011). 
The AMOVA analysis of molecular variance showed that the genetic variation observed in the lulo materials was within each group, with a value of $89 \%$ (Table 5). This high variation could indicate the presence of levels of subdivision and a higher hierarchy than that evaluated in this study. The remaining $11 \%$ was due to the component of genetic variance between the groups; it was significant $(P<0,001)$, indicating the existence of genetic variation between the groups, which can be exploited in conservation processes and breeding programs for this species. Similar results have been found in the assessment of genetic diversity between potato varieties (Solanun tuberosum L.) grown in Mexico using RAPD and ISSR markers.

The use of morphological and molecular markers in the evaluation and characterization of native germplasms provides a much more accurate idea of the genetic structure and diversity of populations and constitutes a valuable tool for the genetic improvement of this species. In this sense, the results found in this study provide the first step in understanding the genetic variability of lulo materials in the province of Neira, which must be preserved and exploited in breeding strategies that lead to better-adapted genotypes with resistance to phytosanitary problems that limit cultivation and with high nutritional quality and agro-industrial potential.

\section{Conclusions}

The morphological characterization showed that the characteristics equatorial axis of the fruit (EJE), fruit weight (PF), juice volume (VJF), polar axis of the fruit (EJP), stem length (LT), pulp color (FCMeso), peel thickness (DEPI) and length of thorns on the stem (TET) provided better differentiation at the intraspecific level.

The analysis with the Nei-Li coefficient resulted in three groups that did not have a direct association with the geographical area or with the presence or absence of thorns (Sepúlveda Delgado, Suárez Aguilar, Patarroyo Mesa, Bautista Díaz, \& Canaria Camargo, 2015). The parameters of genetic diversity showed the existence of a higher genetic diversity than that reported in other studies on lulo and related species in the country.

The combined analysis of the morphological and molecular data provided a better estimate of the genetic diversity and showed that, in the province of Neira, there is 
variability that can be exploited in the collection, conservation and management of germplasms in the search for new and better materials.

\section{Acknowledgments}

The authors express their thanks to the Producers Associations, Pitafcol and Piedras Verdes, CREPIB, Research Competitiveness, Innovation and Business Development (CIDE) and the Directorate General Research (DIN) of the Pedagogical and Technological University of Colombia (UPTC).

\section{References}

(1) Ajoy, K., \& Sailendra, P. (2015). Assessment of genetic diversity among some important wild species of non-tuberous Solanum using RAPD and ISSR markers. International Journal of Pharma and Bio Sciences, 6, 1029-1042.

(2) Cárdenas, Z. (2009). Identificación de híbridos en lulo (Solanum quitoense Lam.) y tomate de árbol (Solanum betaceum Cav.) mediante el uso de marcadores COSII. Pontificia Universidad Javeriana.

(3) Chaparro, S. P., Lara, A. E., Sandoval, A., Sosa, S. J., Martínez, J. J., \& Gil González, J. H. (2015). Functional Characterization of Mango Seeds Kernel (Mangifera indica L.). Ciencia En Desarrollo, 6(1), 67-75. Retrieved http://www.scielo.org.co/scielo.php?script=sci_arttext\&pid=S012174882015000100009\&lng=en\&nrm=iso\&tlng=es

(4) Colombia, A. (2014). Área cosechada, producción y rendimiento de Lulo.

(5) Cortés Díaz, G. M., Prieto Suárez, G. A., \& Rozo Nuñez, W. E. (2015). Caracterización bromatológica y fisicoquímica de la uchuva ( Physalis peruviana L . ) y su posible aplicación como alimento nutracéutico. Ciencia En Desarrollo, 6(1), 87-97.

(6) D. Mejía, A., Gaviria, C., Duque, R., Rengifo, F., \& Aguilar, S. A. (2012). Physicochemical characterization of the lulo (Solanum quitoense Lam.) Castilla variety in six ripening stages. Vitae, 9, 157-162.

(7) Dashchi, S., B. Abdollahi, R. D., \& Bernousi, I. (2012). Molecular similarity relationships among Iranian bread wheat cultivars and breeding lines using ISSR markers. Notulae Botanicae Horti Agrobotanici Cluj-Napoca, 40, 254-260.

(8) E. Zietkiewicz, A., \& Rafalfki, D. L. (1994). Genome fingerprinting by simple sequence repeat (SSR)-anchored polymerase chain reaction amplification. Genome, 20, 176-183.

(9) Enciso, F., Martínez, R., Lobo, M., \& Barrero, L. (2010). Genetic variation in the Solanaceae fruit bearing species lulo and tree tomato revealed by Conserved Ortholog (COSII) markers. Genetics and Molecular Biology, 33, 271-278. 
(10) Fory, P., Sánchez, I., Bohórquez, A., Ramírez, H., Medina, C., \& Lobo, M. (2011). Genetic variability of a Colombian collection of Lulo (Solanum quitoense Lam.) and related species of section Lasiocarpa. Revista Facultad De Agronomía, 63, 5465-5476.

(11) Lobo, M., Medina, C., Delgado, C., \& Bermeo, A. (2007). Variabilidad morfológica de la colección colombiana de lulo (Solanum quitoense Lam.) y especies relacionadas de la sección Lasiocarpa. Revista Facultad Nacional de Agronomía Medellín, 60, 3939-3964.

(12) M. Abdul, Y., \& Singh, N. S. (2015). Marker based assessment of genetic diversity in Aethiopicum and melongena species of genus Solanum. Electronic Journal of Plant Breeding, 6, 904-917.

(13) M. Henareh, A., Dursun, B., Mandoulakani, K., \& Haliloğlu, K. (2016). Assessment of genetic diversity in tomato landraces using ISSR markers. Genetika, 48, 25-25.

(14) M. Riascos, A., Santacruz, T., Lagos, O., \& Checa, O. (2012). Caracterización morfológica de 39 genotipos de la colección de lulo (Solanum quitoense Lam.) de la Universidad de Nariño. Revista de Ciencias Agrícolas, 29, 57-69.

(15) Medina, C., Lobo, M., \& Martínez, E. (2009). Revisión del estado de conocimiento sobre la función productiva del lulo (Solanum quitoense Lam.) en Colombia. Revista Corpoica Ciencia, 10, 167-179.

(16) Miller, J., \& Diggle, P. (2003). Diversification of andromonoecy in Solanum section Lasiocarpa: the roles of phenotypic plasticity and architecture. American Journal of Botany, 90, 707-715.

(17) Muñoz, J., Rodríguez, L., \& Bermúdez, L. (2013). Análisis de competitividad del sistema de producción de lulo (Solanum quitoense Lam.) en tres municipios de Nariño. Revista Colombiana de Ciencias Hortícolas, 7, 173-185.

(18) Nei, M., \& Li, W. (1979). Mathematical model for studying genetic variation in terms of restriction endonucleases. Proceedings of the National Academy of Sciences, 76, 52695273.

(19) Onamu, R., Legaria, J., Rodríguez, J., Sahagún, J., \& Pérez, J. (2016). Molecular characterization of potato (Solanum tuberosum L.) genotypes using random amplified polymorphic DNA (RAPD) and inter simple sequence repeat (ISSR) markers. African Journal of Biotechnology, 15, 1015-1025.

(20) Rodríguez, A., \& Sosa, D. (2015). Caracterización de la diversidad genética de lulo (Solanum quitoense Lam.) en el municipio de Pachavita-Boyacá. Universidad Pedagógica y Tecnológica de Colombia.

(21) S. Dellaporta, J., \& Wood, J. H. (1983). A plant DNA minipreparation: version II. Plant Molecular Biology Reporter, 1, 19-21.

(22) S. Zhang, C., Tang, Q. Z., Li, J., Yang, L., Qie, L., Fan, X., .. Diao, X. (2014). Development of highly polymorphic simple sequence repeat markers using genome-wide microsatellite variant analysis in Foxtail millet [Setaria italica (L.) P. Beauv.]. BMC Genomics, 15. 
81

(23) Sepúlveda Delgado, O., Suárez Aguilar, Z. E., Patarroyo Mesa, M., Bautista Díaz, S., \& Canaria Camargo, L. C. (2015). Estudio del comportamiento e impacto de la climatología sobre el cultivo de la papa y del pasto en la región central de Boyacá empleando los sistemas dinámicos in the Central Region of Boyacá Using Dynamic Systems. Ciencia En Desarrollo, 6(2), 215-224.

(24) Stabilization, O., Plukenetia, I., Linneo, V., Vaccinium, M., Sw, M., \& Addition, S. (2015). Estabilización oxidativa del aceite de Sacha inchi ( Plukenetia volubilis Linneo ) con suspensiones de mortiño ( Vaccinium meridionale SW ). Ciencia En Desarrollo, 6(2), 141153.

(25) Vallejo, M., Montero, L., Cecile, F., Bacles, E., \& Lepais, O. (n.d.). Thirteen microsatellites developed by SSR-enriched pyrosequencing for Solanum rostratum (Solanaceae) and related species. American Journal of Botany, 98.

(26) Wright, S. (1978). Evolution and the genetics of populations. Variability within and among natural populations. Editor University of Chicago, Press., 4, 590.

(27) Xiao, C., Harsh, R., W.Hanwen, Deirdre, L., Geofffrey, E., \& Rex, S. (2013). Development of SSR markers for genetic analysis of Silverleaf Nightshade (Solanum elaeagnifolium) and related species. Plant Molecular Biology Reporter, 31, 248-254.

Table 1. Collection sites from lulo materials evaluated.

\begin{tabular}{|c|c|c|c|c|}
\hline $\mathbf{N}^{\circ}$ & Farm & District & $\begin{array}{l}\text { Altitud } \\
\mathrm{e} \\
\text { (msnm } \\
\text {.) }\end{array}$ & Jescription \\
\hline 1 & $\begin{array}{l}\text { La } \\
\text { playa }\end{array}$ & Soaquira & 2,234 & $\begin{array}{l}\text { Lulo, mixed } \\
\text { or native }\end{array}$ \\
\hline 2 & $\begin{array}{l}\text { Carriz } \\
\text { al }\end{array}$ & $\begin{array}{l}\text { Soaquir } \\
\text { a }\end{array}$ & 2,404 & $\begin{array}{l}\text { Lulo, } \\
\text { smooth and } \\
\text { thorny }\end{array}$ \\
\hline 3 & $\begin{array}{l}\text { San } \\
\text { Eduar } \\
\text { do }\end{array}$ & $\begin{array}{l}\text { Soaquir } \\
\text { a }\end{array}$ & 2,320 & $\begin{array}{l}\text { Lulo, } \\
\text { smooth and } \\
\text { thorny }\end{array}$ \\
\hline 4 & $\begin{array}{l}\mathrm{La} \\
\text { estrell } \\
\text { a }\end{array}$ & $\begin{array}{l}\text { Soaquir } \\
\mathrm{a}\end{array}$ & 2,186 & $\begin{array}{l}\text { Lulo, } \\
\text { smooth and } \\
\text { thorny }\end{array}$ \\
\hline 5 & $\begin{array}{l}\text { San } \\
\text { Antoni } \\
0\end{array}$ & $\begin{array}{l}\text { Sacane } \\
\text { ca }\end{array}$ & 2,148 & $\begin{array}{l}\text { Lulo, } \\
\text { smooth and } \\
\text { thorny }\end{array}$ \\
\hline
\end{tabular}


Table 2. Primers used in the RAMs microsatellite technique.

\begin{tabular}{ll}
\hline Primers & Sequence (5'to 3') \\
\hline CCA & $\mathrm{DDB}(\mathrm{CCA})_{5}$ \\
CGA & $\mathrm{DHB}(\mathrm{CGA})_{5}$ \\
ACA & $\mathrm{BDB}(\mathrm{ACA})_{5}$ \\
$\mathrm{AG}$ & $\mathrm{HBH}(\mathrm{AG})_{7} \mathrm{~A}$ \\
$\mathrm{CT}$ & $\mathrm{DYD}(\mathrm{CT})_{7} \mathrm{C}$ \\
$\mathrm{TG}$ & $\mathrm{HVH}(\mathrm{TG})_{7} \mathrm{~T}$ \\
$\mathrm{CA}$ & $\mathrm{DBDA}(\mathrm{CA})_{7}$ \\
\hline
\end{tabular}

Table 3. Principal Components for each of the evaluated variables.

\begin{tabular}{lccc}
\hline \multicolumn{1}{c}{ VARIABLES } & PC & PC2 & PC3 \\
& $\mathbf{1}$ & & \\
\hline Stem Length (LT) & $\mathbf{0 , 8 8}$ & 0,31 & 0,25 \\
Stem thorn length & 0,24 & 0,22 & $\mathbf{0 , 7 0}$ \\
(TET) & & & \\
Leaf length (LH) & 0,39 & 0,36 & 0,68 \\
Leaf width (AH) & 0,11 & 0,51 & 0,51 \\
Petiole length (LP) & 0,68 & 0,28 & 0,29 \\
№ of & 0,43 & 0,02 & 0,27 \\
Flowers/lnflorescence & & &
\end{tabular}




\begin{tabular}{|c|c|c|c|}
\hline $\begin{array}{l}\text { Polar axis of fruit } \\
\text { (EJP) }\end{array}$ & 0,89 & 0,28 & 0,26 \\
\hline $\begin{array}{l}\text { Equatorial axis of the } \\
\text { fruit (EJE) }\end{array}$ & 0,96 & 0,17 & 0,18 \\
\hline Peel thickness (DEPI) & 0,39 & 0,71 & 0,30 \\
\hline $\mathrm{pH}$ & 0,33 & 0,78 & 0,01 \\
\hline Soluble solids (SS) & 0,69 & 0,35 & 0,28 \\
\hline $\begin{array}{l}\text { Fruit Peduncle length } \\
\text { (LPF) }\end{array}$ & 0,41 & 0,64 & 0,53 \\
\hline Fruit weight (PF) & 0,95 & 0,11 & 0,14 \\
\hline $\begin{array}{l}100 \text { seed weight } \\
\text { (PSF) }\end{array}$ & 0,81 & 0,27 & 0,12 \\
\hline Seeds/fruit weight & 0,32 & 0,65 & 0,27 \\
\hline $\begin{array}{l}\text { Juice volume of } 5 \\
\text { fruits }\end{array}$ & 0,95 & 0,06 & 0,02 \\
\hline Titratable acidity & 0,61 & 0,63 & 0,23 \\
\hline Seed coat color & 0,48 & 0,30 & 0,38 \\
\hline Pulp color & 0,48 & 0.80 & 0,04 \\
\hline Seed color & 0,58 & 0,22 & 0,21 \\
\hline
\end{tabular}

Figure 1. Distribution of the analyzed morpho-agronomic variables of the lulo materials (Solanum quitoense) collected in the municipality of Pachavita- Boyacá. 
84

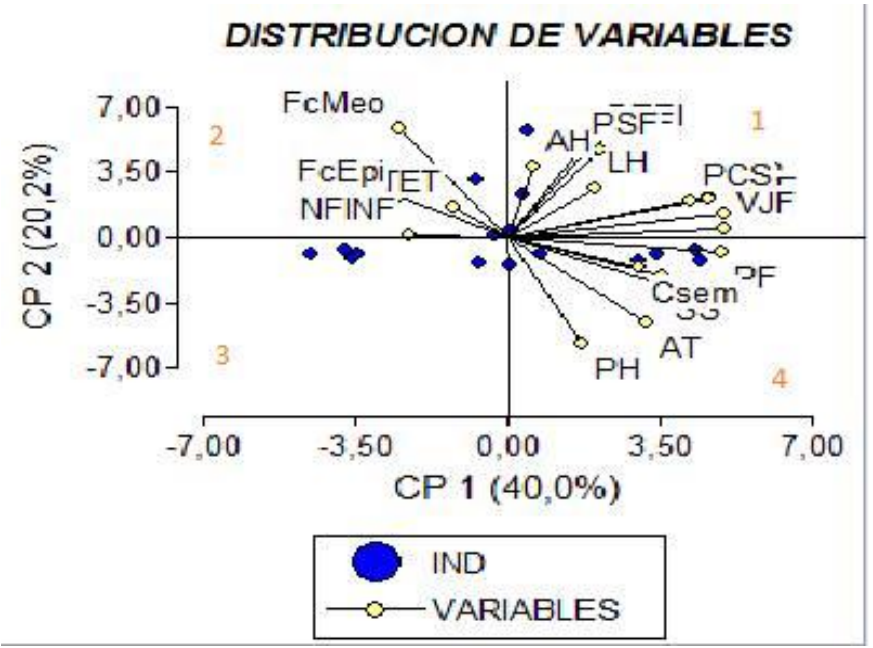

Table 4. Genetic Diversity Parameters estimated in the evaluated Lulo Materials (Solanum quitoense L.).

\begin{tabular}{ccccc}
\hline Primer & Estimated & Polymorphic & Fst & SD \\
& He & loci \% (95\%) & & \\
\hline ACA & 0,35 & 88,6 & 0,11 & 0,02 \\
AG & 0,38 & 100 & 0,19 & 0,04 \\
CA & 0,36 & 95,7 & 0,08 & 0,02 \\
CCA & 0,39 & 95,6 & 0,06 & 0,02 \\
CT & 0,34 & 90,7 & 0,12 & 0,03 \\
TG & 0,33 & 89,6 & 0,22 & 0,03 \\
CGA & 0,40 & 100 & 0,17 & 0,04 \\
TOTAL & $\mathbf{0 , 3 6}$ & $\mathbf{9 4 , 4}$ & $\mathbf{0 , 1 4}$ & $\mathbf{0 , 0 1}$
\end{tabular}


85

Table 5. Molecular Variance Analysis (AMOVA) of the groups.

\begin{tabular}{ccccc}
\hline $\begin{array}{c}\text { Source of } \\
\text { variation }\end{array}$ & GI. & SC & CM & $\%$ \\
\hline Between & & & & \\
groups & 2 & 210.976 & 105.488 & 11 \\
Within Groups & 18 & 1145.024 & 63.612 & 89 \\
Total & 20 & 1356.000 & & 100 \\
\hline
\end{tabular}

*Para citar este artículo: Morillo Coronado A.C.; Rodríguez Fagua A.del P.; Morillo Coronado Y. Morphological and molecular characterization of lulo (Solanum quitoense Lam.) in PachavitaBoyaca. Revista Bistua.2018.16(1):67-85

+ Autor para el envió de correspondencia y la solicitud de las separatas Morillo Coronado A.C. Universidad Pedagógica y Tecnológica de Colombia (UPTC). ana.morillo@uptc.edu.co

Recibido: Diciembre 02 de 2016

Aceptado:Enero 16 de 2018 
Bistua:Revista de la Facultad de Ciencias Básicas.2018.16(1):67-85 